\title{
5.5 Екологічний аспект співіснування людини й природи (на прикладі поезій Л. Костенко)
}

Формування індивіда в процесі цілеспрямованої діяльності суспільства тісно пов'язане із духовно-естетичним сприйняттям довкілля. Адже людина й природа перебувають у безперевному органічному взаємозв'язку, впиваючи одна на одну як позитивно (наприклад, доглянуте екосередовище $є$ запорукою формування міцного здоров'я, отримання естетичної насолоди від споглядання краєвидів тощо), так і негативно (зокрема, глобальні кліматичні зміни стали наслідком безвідповідальної діяльності людства).

В українському письменстві зображення природи є одним із традиційних елементів, що сягають корінням у вікові глибини духовних i народнопоетичних надбань. За допомогою образів природи митці передають почуття, виражають своє ставлення до світу, висловлюють захоплення й замилування мальовничими пейзажами рідної землі. Однак поліфункціональність творчого мислення спонукає майстрів слова й до порушення проблем морально-етичного гатунку, зокрема співіснування людини і природи. Якщо в доцивілізаційні часи людина відчувала себе частинкою круговерті буття, то вивчення його закономірностей та науковотехнічний прогрес призвів до формування ії впевненості у власній безмежній могутності. I тільки 3 часом суспільство знову стало повертатися до усвідомлення всесвітньо взаємозалежних зв'язків. Наразі загострення екологічних проблем, зумовлених впливом людської діяльності на довкілля, перебуває в полі зору фахівців різних галузей міжнародного рівня й спричиняє зростання тривоги людства за майбутнє планети Земля. Щодо гуманітарної реакції на екологічні виклики сучасності, слушною видається думка Л. Статкевич, яка вбачає ii в переосмисленні взаємодії/ стосунків між природою та людиною й актуалізації екокритики [див.: 431, с. 101].

Екоцентричний дискурс української літератури має давні традиції. Він зреалізувався у творчості Г. Сковороди, Т. Шевченка, О. Кобилянської, 
О. Гончара, М. Рильського, Б. Олійника, В. Яворівського та інших. Серед українських митців, що порушують у своїй творчості питання про принципи взаємин людини і природи з погляду різнобічних проекцій, є Л. Костенко. Вивчення поетики художнього зображення світу природи у творах поетеси мала місце в роботах С. Барабаш, В. Брюховецького, М. Ільницького, Г. Клочека, А. Макарова, О. Ковалевського, Т. Салиги та інших. Розвідки, яка б містила вичерпне висвітлення екодомінанти у творчості Л. Костенко, поки що немає. Вибір теми, як і формулювання проблеми дослідження, зумовлено наявністю порушення зазначеної проблеми в ії поезії, що стосуються вивчення і трактування творчості поетеси. Це, власне, і є запорукою актуальності теми наукового студіювання. Мета та завдання роботи - вибрати з творчого доробку Л. Костенко поезії, що торкаються екологічних аспектів співіснування людини i природи, розглянути їх художні особливості крізь призму естетичної концепції творчості авторки загалом.

Природа і людина в мистецькому баченні Л. Костенко простежуються крізь призму обопільної й взаємозумовленої єдності людського та природного мікросвітів, які споконвіку перебувають у безмежжі макросвіту - Всесвіту - як невід’ємні складові. Позитивні чи негативні зміни в їх злагоджених стосунках неодмінно призводять до порушень на всіх рівнях співіснування. С. Ягодзінський, філософськи осмислюючи розвиток людського та природного світів, виокремлює три головні типи їх взаємодії, які умовно позначає «пізнання», «співробітництво» (діалог) та «співрозвиток» (коеволюція) [427]. I ми цілком погоджуємося 3 думкою Н. Криловець, що у творчості поетеси переважають два останні [428].

Лірична героїня Л. Костенко тонко відчуває гармонію й дисбаланс людського та природного світів і дуже чутливо, пропускаючи через серце й душу, їх сприймає: «Мене сьогодні голуб розбудив. / Він прилетів і плакав на балконі» [429, с. 534]. Ïї глибоко хвилює доля всього живого: «Ще назва є, а річки вже немає. / Усохли верби, вижовкли рови / і дика качка тоскно обминає / рудиментарні залишки багви» [429, с. 53], «Ластівки тікають із Свропи. / Що 
поробиш? Скрегіт, регіт, рев. / Чад, бензин, вібрації, галони, - / птиці мертві падають 3 дерев» $[429$, с. 54$]$; «екологічним зойком» спливають в уяві вимерлі види тварин: - «Останній дивогляд морської череди! - / жив тисячу століть, а я вже не застану» [429, с. 55]. Мотив осмислення місця людини і природи у світобудові є провідним у художній рефлексії Л. Костенко.

Концентрує екологічну свідомість реципієнта й спонукає до утвердження думки про обопільну зумовленість і залежність світу природи 3 екзистенційним світом людини поезія «Хутір Вишневий». У факті зникнення одного $з$ осередків поселення людей (а місць таких на території України чимало) - Хутора Вишневого - поетеса побачила втрати кожного на рівні духовному (на разі треба зазначити, що природа в іiі мистецькому стилі одухотворена й персоніфікована). Емоційна наснага розгортається навколо ключового твердження: «Вишневий Хутір... Ні душі». Уже в цій короткій фразі відчувається глибина й гіркота значної втрати, яку посилює образ «зальотного самосія», поважний вік якого підкреслює епітет «сизий, аж смушевий». Авторка наче ненароком зауважує, що лише у його пам'яті хутір «іще Вишневий», і далі перед читачем виринає фреска 3 його спогадом охопленої уяви: «Цвітуть іще ті вишняки, / за обрій стелиться пшениця, і йде у школу навпрошки / маленький хлопчик пішаниця», i «мати свій городець поле». Ця ідилія панувала «там, за порогами, в степах, де землі щедрі і розлогі», де «що не впало проросло» [430, с. 200]. Контрастом до цього є зображення світу природи без людей (це символізує образ хати із забитими вікнами): «Все обступили солонці. / Рілля вродила камінцями. / Стоять порожні криниці, / береться сіль до самих цямрин» [430, с. 201].

Духовні інтенції поезії підсилюються зображенням явних екологічних змін, що виражені у відтворенні образу землі, яка ніколи не звикне до розриву зв'язків між людським і природним світом. Руйнація вікової гармонії буття, спільного для людини й природи, призводить до порушення духовної рівноваги обох. Авторка через місткі лапідарні фрази утверджує думку, що природа ніколи не змириться з втратами, яких зазнало іiі лоно: «Землі хоч 
тисячу століть - / вона не втішиться, не звикне, / що кінь в степу не заірже, / що вже нема верби тієї, / де мертвий хутір стереже / могилу матері твоєї ...» [430, с. 201]. У вірші звучить ще й мотив незнищенності духовних основ, який передається через персоніфікований образ мертвого хутора, який у творі символізує хранителя пам'яті поколінь, i утверджується ідея, що рід безсмертний поки живі пам’ятають про мертвих. «Мертвий хутір»- міцний вузол у низці зруйнованого зв’язку між світом людини й природи.

Чорнобильська трагедія змінила буття пересічного українця й сколихнула світову громадськість, ставши вершиною в усвідомленні примарної техногенної безпеки, а в гуманітарній сфері збурила хвилю рефлексій щодо гострого осмислення проблеми земного співіснування людства. І. Дзюба, аналізуючи вірші Л. Костенко на чорнобильську тему, що ввійшли до збірки «Річка Геракліта», доречно зазначає: «Не справа поезії аналізувати чи облікувати «плюси» i «мінуси» шаленого технологічного прогресу... але хто і як захистить поезію від того суму, яким живе калічена людством природа?» [431, с. 84]. Лихо, що спіткало рідний народ, гострим болем озвалося в серці поетеси. Екологічні візії чорнобильської драми спостерігаємо у віршах «Цей дощ - як душ» [430, с. 152], «Чорні верби над ставом» [430, с. 153], «Страшні корчі вербових ікебан» [430, с. 154], «На березі Прип’яті спить сатана...» [430, с. 207], «Поховані чорнобильські ліси!» [430, с. 209] тощо. У них відчуваються сумні есхатологічні нотки: «...фантом іде, куди його не ждуть. / I тільки села мертвими очима / його у далеч тоскно проведуть» [430, с. 115], «Людей нема, а яблуні цвітуть. / І мертва річка зблискує, як ртуть» [430, с. 154], «День нахмуриться ніччю. Переглянуться зорі. / Озирнеться комета. Заплачуть дощі, / що Земля вже пустельна. І ріки вже хворі, / і немає ж куди повертатись душі» [430, с. 186]. У цих творах можна виокремити низку персоніфікованих художніх образів, що населяють поетичний всесвіт (зорі, комета) та світ природи (дощі, ріки тощо), яким протиставляється уособлений образ атомного реактора, що становить зловіщу глобальну загрозу: «той чорний реактор - i пекло, і трон. / Він спить на піску підібгавши коліна. / I 
сниться йому в ореолі ворон / вже вся Україна, вже вся Україна» [430, с. 207]. Поетеса схиляє до думки, що руйнування світу природи призведе не тільки до фізичного знищення людини, але й духовного.

Не байдужа до історії свого народу Л. Костенко, незважаючи на небезпеку (вважає: «Письменник повинен бачити все» [цит. за 431, с. 153]), взяла участь у експедиції Державного наукового центру захисту культурної спадщини від техногенних катастроф. Чорнобильська тема гірким болем осіла в її серці й рефлексувала в мистецькій творчості.

Уже 3 першого рядочка «Цей дощ - як душ» [430, с. 152] однойменної поезії авторка, використавши смисловий прийом порівняння, стрімко переносить реципієнта в географічно-історичний вимір («Чорнобиль. Зона. Двадцять перший вік» [430, с. 152]), запрошуючи заглянути в минуле, яке не тільки змінило долі мільйонів, але й призвело до безповоротного знищення великого пласту давніх етнокультурних надбань. Зона відчуження навколо Чорнобильської атомної електростанції (ЧАЕС) на тисячоліття залишиться екологічно небезпечною, а поліщуки («ареалом поширення назви... був в основному басейн Прип'яті та її приток» [432] назва унікальної етнографічної групи (субетносу) трапляється в історичних джерелах XV ст. [див: 433, с. 341]) як носії давніх територіальних традицій, елементів побутової культури, діалектних особливостей у мовленні тощо, що на жаль, можуть знівелюватися в національному ідентифікаційному просторі.

I хоч досліджувана поезія сповнена позитивного настрою у відтворенні пишної краси природи, однак контрастно звучать мінорно сумні нотки, що пронизують останню строфу: «Але кленочки проросли крізь ганки. / Жив-був народ над Прип'яттю - i зник. / В Рудому лісі виросли поганки, і ходить Смерть, єдиний тут грибник» [430, с. 152]. У поезії простежуються сумні есхатологічні мотиви. Уособлений образ Смерті, ненароком вкраплений у емоційно наснажений тон твору, змушує реципієнта зауважити, що між природою і людиною таки існує той споконвічний тісний взаємозв'язок, який має безпосередню причетність до світобудови загалом. Однак апріорі природа 
має потенціал відновлення й активно його зреалізовує, а техногенні катастрофи (зокрема, вибух атомного реактора на ЧАЕС), спричиненені людською діяльністю, обертаються глобальними трагедіями насамперед для самого суспільства.

У циклі поезій «Інкрустації», що ввійшли до збірки «Вибране», серед риторичних запитань, які змушують читача замислитися, такі: «Чому ЗвіздаПолин упала в наші ріки?! / Хто сіяв цю біду і хто її пожне? / Хто нас образив, знівечив, обжер? / Яка орда нам гідність притоптала? / Якщо наука потребує жертв, - / чому ж не вас вона перековтала?!» [429, с. 537]. Вони не тільки збуджують свідомість реципієнта, спонукаючи до висновків про відповідальність людей за власні дії та вчинки, а й значно розширюють межі екологічної проблеми, активізуючи питання переосмислення національнопсихологічної гідності, світосприйняття, історичного буття тощо.

Наслідки екологічних катастроф, на жаль, стосуються кожного земного мешканця і вже стали сумною часткою буття світу людей. У збірці «Мадонна Перехресть» [434], яку присвятила коханій доньці, Л. Костенко не змогла оминути цієї болючої теми, помістивши поезії «Не половіють в полі колоски» i «Сніги в снігах», які, треба зауважити, взаємодоповнюють одна одну. Твори об’єднані спільними мотивами та зримо виразною тональністю відтворення місць колишнього побутування людей - місто (Чорнобиль) і село в Зоні відчуження. Художній простір цих геолокацій поетеса зображує в притаманній ій лаконічній стильовій манері, зокрема через інформаційно місткі факти й зорові образи: «В Чорнобиль повертаються казки» [434, с. 60], «Біжить вовчиця... зеленим оком світить на село», «село давно уже як привид», «І виє в ніч вовчиця за селом» [434, с. 61]. Відтак, плавно занурившись у поетичний простір, реципієнт чітко уявляє світ природи без людей і навіть більше - після людей.

Емоційна наснага у творі «Не половіють в полі колоски» [434, с. 60] досягається протиставленням дій - подій, які вербалізовані дієсловами теперішнього часу як із значенням заперечення, так і ствердження: «не 
половіють», «не ходять», «не скачуть» - це про світ людей; «повертаються», «розказують», «плачуть» - про всевишні джерела духовності, що втілені в уособленому образі казок. Саме так бачить авторка той нетлінний місток, що поєднує світ природи та людини. Твір пронизує мотив смутку. Екологічна драма насторожує ліричну героїню.

Поезія «Сніги в снігах» [434, с. 61] - це фрагмент із нинішнього буття на території Чорнобильської зони відчуження, де залишене людьми село опанувала природа, яка заповнила постесхатологічний простір. Раніше заселений людьми топологічний континуум, тепер наповнений уособленими образами: сніги, засипані снігом; ріка, скована кригою; верби, яким «руки 3 холоду звело»; смерть, що «пройшла лісами напролом»; «хмари йдуть», «місяць губи кривить», - відродився й продовжує жити. У поезії простежуємо традиційний неоромантичний мотив вічного існування природи через іiі відродження (воскресіння).

Отже, осмислюючи в поезії проблему співіснування людини і природи, Л. Костенко зауважує їх обопільну залежність та тісний взаємозв'язок із макросвітом - Всесвітом. Безвідповідальна діяльність людства призводить не тільки до техногенних катастроф, знищення біосфери, але й до дисбалансу та руйнації на глибинних рівнях екзистенційного буття. Водночас авторка наголошує на здатності до швидкого самовідновлення природи, а відтак іiі вічного існування, але без людей. Майбутнє суспільства поетеса вбачає в гармонійних взаєминах людини й природи, які також є запорукою збереження основ духовності. 